\title{
PELATIHAN ADVERSITY QUOTIENT DAN UPAYA MENDONGKRAK AKTIVITAS "NONGKRONG" SEBAGAI KEBERHASILAN PEDAGANG WARUNG KOPI DI KAWASAN SENTRA KULINER
}

\author{
SUYANTO
}

\author{
Universitas Yos Sudarso
}

\begin{abstract}
ABSTRAK
Fenomena tingginya pertumbuhan warkop seiring dengan tingginya minat remaja dan masyarakat untuk menghabiskan waktu di cafe ataupun warung kopi (warkop) sebagai gaya hidup. Penelitian ini mengkaji adversity quotient pada pedagang warkop berkenaan dengan tingginya persaingan, dan dampaknya pada kinerja pedagang yang diukur dari segi kuantitas dan kualitas.

Penelitian ini menggunakan metode eksperimen nyata dalam bentuk one design pre test - post test, dengan mengambil pedagang warkop secara incidental sampling. Data dikumpulkan menggunakan angket model skala likert. Hasil uji anava diperoleh nilai $\mathrm{p}=$ $0,000(p<0,05)$ yang berarti ada pengaruh pelatihan terhadap adversity qiotient pada pedagang warkop di sentra kuliner. Hasil analisis regresi linier sederhana diperoleh nilai $p=0,000 \quad(p<0,05)$ yang berarti ada pengaruh adversity quotient terhadap kinerja pedagang. Nilai koefisien determinasi menunjukan adversity quotient mampu memberikan sumbangan efektif terhadap peningkatan kinerja pedagang hingga 55,1\%. Kinerja pedagang juga diketahui dari meningkatnya volume kunnjungan nongkrong di warkop pada kelompok remaja. Volume sebagai indikasi meningkatnya kunjungan diperoleh nilai F sebesar 83,364 dengan probabilitas $0,000 \quad(p<0,05)$ menunjukkan bahwa ada perubahan yang signifikan setelah pedagang mengikuti kegiatan pelatihan.
\end{abstract}

Kata Kunci: Adversity quotient, kinerja pedagang

\section{Pendahuluan}

Di era modern ini tempat nongkrong seperti, coffee shop, cafe, kedai kopi hampir bisa kita temui di setiap tempat, bermunculan kafe-kafe dengan berbagai konsep yang menarik dan didukung sajian minuman dan makanan membuat eksistensi cafe semakin digemari oleh para remaja. "Nongkrong" merupakan kegiatan yang dilakukan anak muda maupun dewasa di suatu tempat untuk berkumpul dan melakukan kegiatan untuk mengisi waktu luang. Fenomena nongkrong itu sendiri menarik minat peneliti untuk melakukan penelitian lebih dalam.

Gaya hidup nongkrong di Indonesia sudah ada sejak jaman dahulu hingga sekarang dan mengalami beberapa perubahan seiring berkembangnya jaman. Pada jaman dulu, nongkrong biasanya hanya dilakukan di warung kopi kecil. Kegiatan yang dilakukan juga lebih sederhana seperti hanya untuk berkumpul bersama teman. Namun dewasa ini, kegiatan nongkrong lebih banyak dilakukan di kafe-kafe ataupun di restoran. Gaya hidup menurut Kotler (2002) adalah pola hidup seseorang di dunia yang diekspresikan dalam aktivitas, minat, dan opininya. Gaya hidup menggambarkan keseluruhan diri seseorang dalam berinteraksi dengan lingkungannya, sedangkan menurut Minor dan Mowen (Widayat, 2010), gaya hidup menunjukkan bagaimana orang hidup, bagaimana 
membelanjakan uangnya, dan bagaimana mengalokasikan waktu, atau gambaran individu dalam berinteraksi dengan lingkungan, termasuk salah satunya adalah nongkrong di cafe-cafe ataupun warung kopi atau dikenal dengan "warkop".

Nongkrong merupakan bahasa pergaulan anak, namun dalam definisi selanjutnya istilah nongkrong menjadi lebih luas. Banyak kegiatan dan aktivitas baik aktif maupun pasif yang kemudian berkembang dari sekedar duduk atau jongkok, seperti seeing, hearing, seating, standing dan staying (Jan Gehl:1987). Nongkrong juga dapat melibatkan orang lain seperti melakukan aktivitas kumpul bersama pada suatu tempat diisikan berbagai kegiatan seperti berbincang dan berbicara dengan orang lain, maupun berkumpulnya kelompok-kelompok orang, mulai dari remaja SMA, Mahasiswa, hingga orang dewasa di cafe, resto atau warungn kopi (Warkop).

Adanya kelompok atau komunitas di kalangan remaja dan yang dikenal dengan sebutan anak muda itulah yang menyebabkan cafe, resto, maupun "warkop" tumbuh berkembang di berbagai kota. Berkaitan dengan hal tersebut, mengacu pada hasil survei awal diketahuim bahwa para mahasiswa yang datang ke café dan warkop faktor pentingnya adalah café dan warkop kini sudah sangat beragam dan pilihan harganya juga menjangkau semua kalangan mulai dari yang kalangan atas ekonomi kelas menengah kebawah. Keberadaan café dan warkop mengubah ritme gaya hidup mahasiswa maupun siswa SMA. Kegiatan nongkrong ini menurut penelitian Arditya (2010) sudah menjadi gaya hidup yang konsumtif karena nongkrong di café maupun "Warkop" adalah suatu kegiatan yang selalu dilaksanakan setiap akhir pekan bahkan di setiap malam suasana cafe maupun "warkop" tetap penuh dan ramai dikunjungi dengan alasan mengisi waktu luang.

Berkenaan dengan hal tersebut, bagaimana upaya pedagang khususnya "warkop" dapat mengembangkan potensi pasarnya agar dapat menarik konsumen pemuda untuk singgah dan nongkrong di warkopnya. Hal itu tidak mudah, karena cukup banyak pengelola waarkop yang gagal dan tutup dalam beberapa bulan karena rendahnya pengunjung. Untuk itu melatih daya juang (adversity quotient) dan kinerja pengelola harus ditingkatkan agar warkop sebagai tempat usahanya dapat bertahan dalam kurun waktu yang lama dan berkembang sebagai tempat berkumpulnya anak-anak muda yang dikenal dengan istilah "nongkrong di warkop". Nongkrong adalah suatu trend terus dikuti oleh kelompok mahasiswa maupun siswa SMA hingga kelangan dewasa pada zaman sekarang, dan pengelolaan tempat nongkrong bukan sekedar fasilitas dan harga saja yang menarik minat pengunjung, namun juga daya juang dan kinerja pengelolanya dalam memberikan layanan dan kreasi yang unik, agar pengunjung merasa betah berlamalama di tempat nongkrong.

\section{Tujuan Penelitian}

Berdasarkan permasalahan yang dikemuakakan, maka tujuan penelitian ini adalah untuk

1. Membuktikan adanya pengaruh pelatihan terhadap adversity quotient pedagang warkop di sentra kuliner surabaya

2. Mengetahui pengaruh adversity quotient terhadap kinerja pedagang dalam meningkatkan kunjungan nongkrong di warung kopi di sentra kuliner.

\section{Kajian Teori}

\subsection{Pelatihan Adversity Quotient}

Robbins (2013) menjelaskan bahwa pelatihan adalah suatu proses belajar mengenai sebuah wacana 
pengetahuan dan keterampilan yang ditujukan untuk penerapan hasil belajar yang sesuai dengan tuntutan tertentu. Selanjutnya Mathis (2012), menjelaskan bahwa pelatihan adalah suatu proses dimana orang-orang mencapai kemampuan tertentu untuk membantu mencapai tujuan individu dan atau organisasi. Istilah pelatihan tidak terlepas dari latihan karena keduanya memiliki hubungan yang erat, latihan adalah kegiatan atau pekerjaan melatih untuk memperoleh kemampuan atau kecakapan. Sedangkan tujuan dari kegiatan pelatihan adalah untuk meningkatkan pengetahuan dan keterampilan dalam memahami dan melaksanakan suatu pekerjaan dengan efektif dan efisien. Menurut (Goldstein, dalam Huda, 2015), pelatihan merupakan proses pendidikan jangka pendek yang menggunakan cara dan prosedur yang sistematis dan terorganisir. Para peserta pelatihan akan mempelajari akan mempelajari pengetahuan dan keterampilan yang sifatnya praktis untuk tujuan tertentu.

Dalam memilih metode dan teknik suatu pelatihan ditentukan oleh banyak hal. Seperti dikemukakan Werther (Davis dan Neswtrom, 2008) sebagai berikut: that is no simple technique is always best; the best method depends on: cost effectiveness; desired program content; learning principles; appropriateness of the facilities; trainee preference and capabilities; and trainer preferences and capabilities. Artinya tidak ada satu teknik pelatihan yang paling baik, metode yang paling baik tergantung pada efektivitas biaya, isi program yang diinginkan, prinsipprinsip belajar, fasilitas yang layak, kemampuan dan preference peserta serta kemampuan dan preference pelatih. Walaupun demikian, pengelola pelatihan hendaknya mengenal dan memahami semua metode dan teknik pelatihan, sehingga dapat memilih dan menentukan metode dan teknik mana yang paling tepat digunakan sesuai dengan kebutuhan, situasi dan kondisi yang ada.

\subsection{Daya Juang (Adversity Quetiont)}

Adversity Quotient (AQ) adalah metode yang paling ilmiah, paling kuat dan banyak digunakan di dunia untuk mengukur dan memperkuat ketahanan manusia. Singkatnya, metode yang mempelajari tentang kemampuan seseorang dalam menghadapi masalah. Nashori (Mafra, dan Turipan, 2017) berpendapat bahwa daya juang merupakan kemampuan seseorang dalam menggunakan kecerdasan untuk mengarahkan, mengubah cara berfikir dan tindakannya ketika menghadapi hambatan dan kesulitan yang bisa menyengsarakan dirinya. Sedangkan Leman (Sudarmanto, 2009) mendefinisikan daya juang sacara ringkas, yaitu sebagai kemampuan seseorang untuk menghadapi masalah.

Selanjutnya diungkapkan Stoltz (2000) daya juang sebagai kecerdasan seseorang dalam menghadapi rintangan atau kesulitan secara teratur. Daya juang membantu individu memperkuat kemampuan dan ketekunan dalam menghadapi tantangan hidup sehari-hari seraya tetap berpegang teguh pada prinsip dan impian tanpa memperdulikan apa yang sedang terjadi.

Berdasarkan uraian diatas dapat disimpulkan bahwa daya juang (adversity quotient) adalah kemampuan seseorang dalam menghadapi dan bertahan terhadap kesulitan hidup sebagai suatu proses untuk mengembangkan diri, dan mencapai suatu tujuan tertentu.

Menurut Stoltz (2000) aspekaspek daya juang (adversity quotient) ada empat dimensi, yaitu:

a. Control (kendali). Kendali adalah kemampuan pedagang dalam mengendalikan permasalahan yang dihadapi, dapat mengkondisikan emosi, dapat mengambil seluruh tantangan, dan lebih berani dan optimal. 
b. Origin dan ownership (asal usul dan pengakuan) adalah sejauh mana pedagang mempu menghadapi akibat-akibat yang ditimbulkan oleh situasi sulit tertentu. Pedagang yang memiliki tingkat origin yang lebih tinggi akan berpikir bahwa ia merasa saat ini bukan waktu yang tepat, setiap orang akan mengalami masa-masa yang sulit, atau tidak ada yang dapat menduga datangnya kesulitan. Dimensi ownership kesanggupan mengakui akibat yang ditimbulkan dari situasi yang sulit, yang mencerminkan sikap tanggung jawab.

c. Reach (jangkauan), yakni sejauh mana kesulitan akan menjangkau bagian lain dari pedagang, seperti sikap, perhatian, dapat membatasi kesulitan dan segera menyelesaikannya.

d. Endurance (daya tahan) adalah kecepatan dan ketepatan pedagang dalam memecahkan masalah, sehingga aspek ini dapat dilihat beberapa lama kesulitan akan berlangsung dan beberapa lama penyebab kesilitan itu akan berlangsung. Seseorang yang mempunyai daya tahan yang tinggi akan memiliki harapan dan sikap optimis dalam mengatasi kesulitan atau tantangan yang sedang dihadapi.

Berdasarkan uraian diatas dapat ditarik kesimpulan bahwa aspek-aspek daya juang yang terdiri dari kendali, origin dan ownwership (asal usul dan pengakuan), reach (jangkauan), dan endurance (daya tahan).

\subsection{Kinerja Pedagang}

Byars (dalam Kreitner and Kincichi, 2010), kinerja diartikan sebagai hasil usaha yang dicapai seseorang dengan adanya kemampuan dan perbuatan dalam situasi tertentu. Dapat juga dikatakan sebagai prestasi kerja, yang merupakan hasil keterkaitan antara usaha, kemampuan dan persepsi tugas. Usaha merupakan hasil motivasi (fisik atau mental) yang digunakan oleh seseorang dalam menjalankan suatu tugas. Sedangkan kemampuan merupakan karakteristik individu yang digunakan dalam menjalankan suatu pekerjaan, sedangkan persepsi tugas merupakan petunjuk dimana individu percaya bahwa seseorang dapat mewujudkan usaha-usaha dalam menyelesaikan pekerjaan.

\begin{tabular}{lrr}
\multicolumn{2}{c}{ Rich, Gregory (dalam Munandar, } \\
2012), mengemukakan & kinerja \\
dianggap lebih dari & sekedar \\
produktivitas & karena & kinerja
\end{tabular}
menyangkut perilaku alami yang dimiliki seseorang untuk bebas melakukan tindakan sesuai keinginannya. Perilaku bebas untuk bertindak ini tetap tidak bisa dilepaskan syarat-syarat formal peran seorang karyawan untuk meningkatkan fungsi efektif suatu organisasi. Sedangkan Dessler (dalam Astuti 2015) mendefinisikan kinerja atau prestasi kerja yaitu perbandingan antara hasil kerja yang secara nyata dengan standar kerja yang ditetapkan, dengan demikian kinerja memfokuskan pada hasil kerjanya. Sedangkan Gomes (Munandar, 2012), menyatakan kinerja sebagai catatan terhadap hasil produksi dari sebuah hasil pekerjaan tertentu atau aktiviats tertentu dalam periode waktu tertentu. Mangkunegara (2006) juga mendefinisikan kinerja sebagai hasil kerja baik secara kualitas maupun kuantitas yang dicapai oleh seseorang dalam melaksanakan tugas sesuai tanggung jawab yang diberikan. Menurut Veithzal (2014), kinerja adalah kesediaan seseorang atau kelompok orang untuk melakukan sesuatu kegiatan dan menyempurnakannya sesuai dengan tanggung jawab dengan hasil seperti yang diharapkan. Lebih lanjut dijelaskan kinerja pada dasarnya ditentukan oleh tiga hal, yaitu: 1) Kemampuan, 2) Keinginan, dan 3) Lingkungan. Lebih lanjut Rivai dan Basri (Rusdiyanto, 2014) juga menyebutkan ada empat aspek kinerja yaitu : 
a. Kemampuan, yaitu kesanggupan seseorang untuk melaksanakan tugas-tugas pekerjaan dengan target atau harapan yang ditetapkan, dalam hal ini adalah kemauan untuk menambah sarana atau fasilitas serta layanan

b. Penerimaan tujuan, yaitu kesanggupan untuk menerima hasil dan mengakui setiap kekurangan berdasarkan hasil evaluasi.

c. Tingkat tujuan yang dicapai, yaitu menetapkan target dan sasaran yang direncanakan dengan jumlah yang juga telah ditetapkan, dalam penelitian ini adalah peningkatan volume pengunjung

d. Interaksi antara tujuan dan kemampuan, yaitu adanya keselarasan antara harapan, usaha, dan hasil yang hendak dicapai.

Berdasarkan pengertian kinerja dari beberapa pendapat diatas, maka dapat disimpulkan bahwa kinerja merupakan hasil kerja yang dicapai pedagang dengan standar yang telah ditentukan. Kinerja juga berarti hasil yang dicapai oleh seseorang, baik kuantitas maupun kualitas dalam suatu usaha sesuai dengan tanggung jawab yang diberikan kepadanya yang diukur dengan standar yang telah ditentukan, yang dalam penelitian ini adalah volume pengunjung.

\section{Hipotesis}

Berdasarkan permasalahan, tujuan penelitian dan kajian teori yang disampaikan, maka hipotesis yang diajukan sebagai berikut.

a. Ada pengaruh pelatihan terhadap adversity quotient pada pedagang warung kopi di sentra kuliner

b. Ada pengaruh adversity quotient terhadap kinerja pedagang dalam meningkatkan kunjungan nongkrong di warung kopi di sentra kuliner.

\section{Metode Penelitian} 5.1 Populasi dan Sampel Penelitian
Populasi dalam penelitian ini adalah pedagang warung kaki lima atau WARKOP, yang menurut data kecamatan di area sentra kuliner di kawasan Semolowaru terdapat kurang lebih sekitar 242 Warkop dan Cafe-cafe tempat nongkrong remaja, baik siswa SMA maupun Mahasiswa dan orang tua.

Berkenaan dengan jumlah populasi tersebut, maka diambil 34 pedagang dengan metode incidental sampling, yaitu mengambil sampel pedagang yang kebetulan ditemui dan bersedia mengikuti kegiatan pelatihan serta mengisi angket penelitian. Prosedur pengambilan sampel dilakukan dengan cara menawarkan kegiatan pelatihan, dan sampel mengisi informed concent yaitu kesediaan mengikuti pelatihan serta menjadi sampling penelitian dalam kurun waktu pre dan post penelitian sekitar 1 (satu) bulan)

\subsection{Desain Penelitian}

Penelitian ini menggunakan desain eksperimen, yaitu one design pre test post test untuk mengetahui dampak pelatihan dan dilakukan pengujian pengaruh sebagaimana gambar berikut.

(1) $\mathrm{Y} \square \mathrm{X} \square \mathrm{Y} 1:$ : (2) $\mathrm{Y} 1 \square \mathrm{Y} 2$

Keterangan

$Y$ : Pre test (pengambilan data sebelum pelatihan)

$X$ : Pemberian Pelatihan adversity quotient

Y1 : Post test (pengambilan data setelah pelatihan)

$\mathrm{Y} 1 \square \mathrm{Y} 2 \quad$ : Uji pengaruh pelatihan adversity quotient terhadap kinerja

Dalam penelitian eksperimen ini tidak dugunakan kelompok kontrol sebagai pembanding.

\subsection{Teknik Pengambilan Data}

Dalam penelitian ini pengambilan data dilakukan menggunakan angket penelitian 
dengan indikator-indikator yang telah dibangun sesuai dengan teori yang dikemukakan. Angket disusun menggunakan skala model likert dengan 5 pilihan jawaban tertutup.

Proses pengambilan data pada kelompok yang diberikan pelatihan, atau subjek penelitian diberikan angket pre test sebelum mengikuti pelatihan. Selanjutnya pelatihan dilaksanakan selama tiga hari atau selama 32 jam. Angket post test diberikan setelah seminggu kegiatan pelatihan.

Selanjutnya hasil pengujian validitas dan reliabilitas dilakukan sebagai persyaratan keabsahan data sebagai berikut.

Tabel 1. Hasil uji validitas dan reliabililtas

\begin{tabular}{c|r|r}
\hline Skala & Nilai Validitas & Nilai Reliabilitas $\alpha$ \\
\hline Adversity quotient & $0,541-0,804$ & 0,814 \\
\hline Kinerja pedagang & $0,609-0,703$ & 0,857 \\
\hline
\end{tabular}

Berdasarkan hasil pengujian validitas dan reliabilitas diketahui bahwa pada masing-masing skala memiliki nolai koefisien validitas lebih dari 0,30. Menurut Azwar (2014) bahwa koevisien validitas dapat diukur dengan indeks diskriminasi butir lebih dari 0,30. Berdasarkan pertimbangan tersebut, maka pada masing-masing butir dapat dikatakan valid.

Hasil uji homogenitas menggunakan Levene diperoleh nilai 0,198 dengan probabilitas sebesar $0,658(p>0,05)$ yang berarti data-data yang diperoleh tergolong tidak memiliki masalah dalam homogenitas (Ghazali, 2015).

\subsection{Teknik Analisis Data}

Untuk mengetahui dampak pelatihan terhadap adversity quotient pada para pedagang digunakan teknik
Nilai koefisien reliabilitas alpha Cronbach's pada masing-masing skala diperoleh nilai lebih dari 0,70 , dan menurut Silalahi (2012) dan Ghazali (2014) bahwa dalam penelitian sosial, skala dapat dikatakan memiliki reliabilitas bila memiliki nilai lebih dari 0,70 . Hasil pengujian tersebut menunjukkan bahwa seluruh skala yang dipakai dalam penelitian ini tergolong handal.

Hasil uji asumsi homogenitas menunjukkan sebagai berikut.

Tabel 2. Test of Homogeneity of Variances

\begin{tabular}{|c|c|c|c|}
\hline $\begin{array}{l}\text { Levene } \\
\text { Statistic }\end{array}$ & df1 & $\mathrm{df2}$ & Sig. \\
\hline .198 & 1 & 66 & .658 \\
\hline
\end{tabular}

analisis varian satu jalur (Anova), sedangkan untuk analisis uji pengaruh digunakan teknik regresi linier (Silalahi, 2012).

\section{Hasil Penelitian}

Hasil penelitian, yang pertama adalah mengetahui adanya pengaruh pelatihan terhadap adversity quotient pada para pedagang warkop sebagai berikut.

Tabel 3. Hasil uji dampak pelatihan adversity quotient 
ISSN 1412-2936

EISSN 2549-7308

\begin{tabular}{|c|c|c|c|c|c|}
\hline & $\begin{array}{l}\text { Sum of } \\
\text { Squares }\end{array}$ & df & Mean Square & $\mathrm{F}$ & Sig. \\
\hline $\begin{array}{l}\text { Between Groups } \\
\text { Within Groups } \\
\text { Total }\end{array}$ & $\begin{array}{l}476.471 \\
436.765 \\
913.235\end{array}$ & $\begin{array}{r}1 \\
66 \\
67\end{array}$ & $\begin{array}{r}476.471 \\
6.618\end{array}$ & 72.000 & .000 \\
\hline
\end{tabular}

Hasil uji Analisis varian diketahui nilai $F=72,000$ dengan probabilitas sebesar $0,000 \quad(p<0,05)$ yang berarti ada perubahan yang signifikan antara pre tes dengan post test. Nilai rerata positif (mean square) menunjukkan bahwa nilai post test lebih besar dibandingkan nilai pre test. $\mathrm{Hal}$ ini dapat dikatakan bahwa hipotesesi yang menyatakan ada pengaruh pelatihan terhadap adversity quotient pada pedagang warkop di sentra kuliner dapat diterima.

Hasil pengujian perbedaan volume kunjungan sebelum dan sesudah kegiatan pelatihan diketahui sebagai

berikut.

Tabel 4. Hasil uji perubahan volume sebelum dan sesudah pelatihan

\begin{tabular}{l|r|r|r|r|r}
\hline & $\mathrm{N}$ & Mean & $\begin{array}{c}\text { Std. } \\
\text { Deviation }\end{array}$ & $\mathrm{F}$ & \multicolumn{1}{|c}{ Sign. } \\
\hline Sebelum latihan & 34 & 15.6176 & 2.51076 & 83.364 & .000 \\
Sesudah latihan & 34 & 20.3529 & 1.68563 & & \\
Total & 68 & 17.9853 & 3.19277 & & \\
\hline
\end{tabular}

Berdasarkan data hasil analisis uji beda volume kunjungan, diketahui nilai rerata sebelum dilakukan dan sesudah dilakukan pelatihan positif, yakni volume kunjungan setelah pedagang mengikuti pelatihan lebih besar dibandingkan sebelum kegiatan pelatihan. Nilai $\mathrm{F}$ sebesar 83,364 dengan probabilitas $0,000 \quad(p<0,05)$ menunjukkan bahwa ada perubahan yang signifikan setelah pedagang mengikuti kegiatan pelatihan.

Selanjutnya hasil pembuktian hipotesis kedua menggunakan analisis regresi dapat diketahui sebagai berikut

Tabel 5. Uji Analisis Regresi Linier

\begin{tabular}{c|r|r|r|r|r|r}
\hline \multirow{2}{*}{$\mathrm{R}$} & \multirow{2}{*}{ R Square } & \multicolumn{5}{|c}{ Change Statistics } \\
\cline { 3 - 7 } & & $\begin{array}{c}\text { R Square } \\
\text { Change }\end{array}$ & F Change & \multicolumn{1}{c|}{ df1 } & df2 & $\begin{array}{c}\text { Sig. F } \\
\text { Change }\end{array}$ \\
\hline $.742^{\mathrm{a}}$ & .551 & .551 & 39.241 & 1 & 32 & .000 \\
\hline
\end{tabular}

Nilai $\mathrm{R}$ sebesar 0,742 menunjukkan bahwa koefisien korelasi antara adversity qiotient pada pedagang dengan kinerja pedagang tergolong cukup tinggi. Sedangkan nilai F sebesar 39,241 pada taraf signifikansi 5\%, df2 diperoleh nilai 4,263 ( $F>4,263$ ), dan nilai probabilitas sebesar $0,000 \quad(p<0,05)$ yang berarti terdapat pengaruh signifikan. Nilai koefisien determinasi sebesar 0,551 menunjukkan bahwa adversity qiotient mampu memberikan sumbangan efektif terhadap kinerja pedagang sebesar $55,1 \%$.

Berdasarkan hasil analisis uji regresi linier tersebut dapat diketahui bahwa hipotesis yang menyatakan ada 
pengaruh pelatihan adversity quotient terhadap kinerja pedagang dalam menarik minat nongkrong pada remaja di warkop sentra kuliner di Surabaya.

\section{Bahasan}

\subsection{Pengaruh pelatihan terhadap adversity quotient}

Hasil pembuktian melalui analisis varian pada pengaruh pelatihan terhadap adversity quotient melalui teknik one design pre test - post test diperoleh nilai probabilitas kurang dari $5 \% \quad(p<0,05)$ yang berarti bahwa hipotesis yang menyatakan ada pengaruh pelatihan terhadap adversity qiotient pada pedagang warkop di sentra kuliner dapat diterima. Nilai positif pada rerata menunjukkan bahwa post test atau kemampuan adversity quotient pada pedagang lebih tinggi setelah mengikuti kegiatan pelatihan. Hal ini dapat dikatakan bahwa pemberian pelatihan terhadap pedagang warkop tergolong cukup efektif.

Stoltz (Mafra dan Turipan, 2017) berprndapat bahwa adversity quotient merupakan kemampuan seseorang dalam menggunakan kecerdasan untuk mengarahkan, mengubah cara berfikir dan tindakannya ketika menghadapi hambatan dan kesulitan yang bisa menyengsarakan dirinya. Sedangkan Sudarmanto (2009 mendefinisikan daya juang sacara ringkas, yaitu sebagai kemampuan seseorang untuk menghadapi masalah. Selanjutnya diungkapkan Stoltz (2000) adversity quotient atau daya juang sebagai kecerdasan seseorang dalam menghadapi rintangan atau kesulitan secara teratur. Menurut Davis dan Neswtrom (2008), daya juang membantu individu memperkuat kemampuan dan ketekunan dalam menghadapi tantangan hidup seharihari seraya tetap berpegang teguh pada prinsip dan impian tanpa memperdulikan apa yang sedang terjadi.
Adanya pengaruh pelatihan adversity quotient pada pedagang warkop tersebut memberikan gambaran bahwa pelatihan menumbuhkan kemampuan dan kesiapan akan daya saing. Ini dapat dikatakan bahwa dalam blok atau kawasan sentra kuliner terdapat lebih dari dua warkop, dan tidak jauh dari lokasi sentra kuliner juga terdapat beberapa warkp bahkan cafecafe yang menawarkan fasilitas dan kenyamanan. Pelatihan adversity quotient menunjukan bahwa daya juang yang tinggi dapat ditumbuhkan manakala pedagang memahami adanya kompetisi, daya saing ketika menghadapi kesulitan, sehingga memunculkan kemampuan untuk menciptakan, peluang dalam kesulitan yang dihadapi.

\subsection{Pengaruh Adversity quotient terhadap kinerja pedagang}

Hasil analisis uji pengaruh adversity quotient terhadap kinerja pedagang dan minat pengunjung diketahui dari hasil analisi uji regresi linier sederhana, yang diperoleh nilai probabilitas kurang dari $5 \%(p<0,05)$. Hal tersebut menunjukkan bahwa hipotesis yang menyatakan ada pengaruh adversity quotient terhadap kinerja pedagang dapat diterima. Diterimanya hipotesis ini juga didukung oleh nilai koefisien determinasi, yang adversity quotient mampu memberikan sumbangan efektif terhadap peningkatan kinerja pedagang hingga $55,1 \%$.

Menurut Veithzal (2014), kinerja adalah hasil atau tingkat keberhasilan seseorang atau perusahaan secara keseluruhan selama periode tertentu di dalam melaksanakan tugas. Kinerja pedagang merupakan suatu tujuan usaha yaitu dapat memberikan kepuasan kepada pembeli dan masyarakat yang lain dalam pertukarannya untuk sejumlah laba atau perbandingan antara penghasilan dan biaya menguntungkan (Widayat, 2010). Kemudian disimpulkan indikator 
kinerja pedagang yaitu peningkatan pembeli, peningkatan penjualan dan peningkatan efisiensi. Purchasing atau pembelian sinonim dengan procurement atau pengadaan barang. Kemudian Maheka (2012), menjelaskan penjualan adalah interaksi antara individu saling bertemu muka yang ditujukan untuk menciptakan, memperbaiki, menguasai atau mempertahankan hubungan pertukaran sehingga menguntungkan bagi pihak lain.

Hasil penelitian menjelaskan bahwa adversity quotient berpengaruh positif dan signifikan terhadap kinerja pedagang warkop di sentra kuliner Surabaya. Untuk memperoleh adversity quotient yang tinggi, perlu dilakukan pengembangan pekerjanya melalui pelatihan, penelitian ini mendukung penelitian yang dilakukan oleh Hudi (2013), hasil penelitian menyatakan terdapat pengaruh yang nyata antara variabel pengembangan sumber daya manusia terhadap kualitas sumber daya manusia. Artinya apabila peran dari pengembangan sumber daya manusia ditingkatkan maka kualitas sumber daya manusia dan kinerja yang ada akan ikut meningkat. Menurut Widayat (2010) Sumber daya yang dimiliki pedagang merupakan hal penting yang harus ditingkatkan demi mencapai tujuan dalam meningkatkan pendapatan serta kualitas barang dagangan mereka yang dapat bersaing dengan kompetitif.

Selain itu kinerja pedagang juga dapat diketahui dari meningkatnya minat nongkrong di warkop pada kelompok remaja, yang kinerja ini dapat diukur melalui peningkatan volume kunjungan. Nilai $F$ sebesar 83,364 dengan probabilitas $0,000 \quad(p<0,05)$ menunjukkan bahwa ada perubahan yang signifikan setelah pedagang mengikuti kegiatan pelatihan. Hasil pelatihan yang berdampak pada kinerja dan volume nongkrong tersebut memberikan dampak pada volume penjualan dan pendapatan. Hal ini dapat dikatakan bahwa efek adversity quotient secara langsung mampu meningkatkan kinerja pedagang yang diukur melalui volume kunjungan atau jumlah remaja yang nongkrong di warkop sentra kuliner di Surabaya.

\section{Simpulan}

Berdasarkan hasil penelitian dan pembahasan dapat disimpulkan sebagai berikut.

a. Ada pengaruh pelatihan terhadap adversity quotient (daya juang) pedagang warkop di sentra kuliner Surabaya.

b. Ada pengaruh adversity quotient terhadap kinerja pedagang warkop terutama dari aspek peningkatan volume kunjungan maupun kinerja keuangan.

\section{Daftar Pustaka}

Arditya, D. (2010). Perbedaan Perbedaan Intensi Berwirausaha Pada Mahasiswa Ditinjau Dari Karakter Kecerdasan Adversity. Skripsi (tidak diterbitkan). Surakarta: Fakultas Psikologi UMS.

Astuti, W (2015). Pengaruh adversity quotient dan kepuasan kerja terhadap kinerja karyawan di PT. Propan Raa Sidoarjo. Thesis Program Pascasarjana, fakultas Psikologi Universitas 17 Agustus Surabaya.

Azwar, S (2014). Validitas dan reliabilitas alat ukur. Yogyakarta: Pustaka Pelajar,

Davis dan Neswtrom, J.W (2008). Perilaku dalam Organisasi, Jilid 1, edisi ketujuh. Penerbit Erlangga. Jakarta

Ghazali, I (2014). Analisis Multivariate dengan Program SPSS. Penerbit Universitas Semarang. 
ISSN 1412-2936

EISSN 2549-7308

Hadi, S (2013). Statistik 2. Andi Offset, Jogjakarta.

Huda, M. (2015). Pengaruh pelatihan terhadap motivasi kerja dan kinerja karyawan di RS. BR Surabaya. Thesis Program Pascasarjana, fakultas Psikologi Universitas 17 Agustus Surabaya.

Kreitner, R., and Kincichi, A (2010). Organizational Behavior, 3rd Edition, By. Richard D. Irwin Inc.Printed in The United State of America.

Mafra, N.U., dan Turipan. (2017). Pengaruh kepuasan kerja dan semangat kerja terhadap produktivitas kerja pegawai pada distrik navigasi Kelas I Palembang. Jurnal Ecoment Global : Kajian Bisnis dan Manajemen, Vol. 2, No. 2, p: $34-40$

Maheka, A. (2012). Bagaimana Mendirikan dan Mengelola Bisnis Secara Baik dan Aman. Yogyakarta: Kanisius.

Mangkunegara, A.P (2006). Evaluasi Kinerja SDM. Cetakan Pertama. PT. Refika Aditama, Bandung.

Mathis, R.L. and Jackson, J.H., (2012). Human Resource Management, $9^{\text {th }} \quad$ Edition, South- Western Publishing, Ohio.

Munandar, A.S. (2012). Psikologi Industri dan Organisasi. Lembaga Pengembangan Sarana Pengukuran dan Pendidikan Psikologi (LPSP3), Fakultas Psikologi Universitas Indonesia, Jakarta

Robbin, S.P (2013). Perilaku Organisasi : Konsep, Kontroversi dan Aplikasi, Jilid I, PT. Prehalindo Persada, Jakarta

Rusdiyanto. (2014). The Role of Human Resourches Research. Hand out, diktat Kuliah, Universitas Surabaya. Fakultas IImu Ekonomi Manajemen.

Silalahi, U. (2012). Metode Penelitian Sosial. Bandung: Refika Aditama.

Stoltz, P.G. (2000). Adversity Quotoient, Mengubah Hambatan Menjadi Peluang (diterjemahkan oleh T Hermaya). Jakarta: PT Gramedia Widiasarana Indonesia.

Sudarmanto (2009). Kinerja dan Pengembangan Kompetensi SDM Teori, Dimensi dan Implementasi dalam Organisasi. Yogyakarta; Pustaka Pelajar

Veithzal, R. 2014. Manajemen Sumber Daya Manusia untuk Perusahaan dari Teori ke Praktik. CetakanPertama, Jakarta : Penerbit PT. Raja Grafindo Persada.

Widayat, (2010), Perilaku berinvestasi preseptif mixed method, Aditya Media Publishing, Yogyakarta. 